\footnotetext{
JURNAL CEMERLANG: Pengabdian pada Masyarakat

P-ISSN 2654-4741 / E-ISSN 2655-7894

Vol. 2, No. 2, Juni 2020, 173 - 183

DOI: https://doi.org/10.31540/jpm.v2i2.920

PENERBIT: LP4MK STKIP PGRI LUBUKLINGGAU
}

\title{
WORKSHOP PEMANFAATAN E-LEARNING SCHOOLOGY DALAM PEMBELAJARAN PADA GURU SMP BAKTI IBU 11 LUBUKLINGGAU
}

\author{
Dodik Mulyono, Yeni Asmara \\ STKIP PGRI Lubuklinggau, Indonesia \\ Email: yeni.stkip@gmail.com
}

\begin{abstract}
ABSTRAK
Tujuan kegiatan ini membantu guru SMP BI dalam membuat media pembelajaran dengan menggunakan E-Learning Schoology. Metode yang digunakan dalam kegiatan ini adalah ceramah yang dikombinasikan dengan metode demosntrasi dan latihan. Selanjutnya di akhir kegiatan akan diberikan evaluasi kepada guru yang mengikuti kegiatan tersebut dengan indikator keberhasilan kemampuan guru dalam menggunakan e-learning dalam hal ini Schoology. Dari hasil evaluasi diketahui sebanyak 53 guru hanya 20 orang guru atau $37.73 \%$ yang dapat mengaplikasikan elearning:schoology sesuai dengan bidang studinya masing-masing. Dan 15 orang guru atau $28.30 \%$ baru berhasil membuat akun aplikasi dari e-learning schoology dikarenakan tidak menggunakan laptop tetapi menggunakan HP. 18 orang guru atau $33.96 \%$ belum dapat membuat akun dan mengaplikasikan e-learning schoology dikarenakan terkendala tidak membawa laptop dan HP serta belum memiliki e-mail pribadi. Pertemuan kedua ada 45 orang guru atau $84.90 \%$ guru yang telah memiliki akun dan membuat aplikasi e-learning:schoology sesuai dengan bidang studinya masing-masing. Dan 8 orang atau $15.09 \%$ guru sampai pada tahap pembuatan akun. Dengan demikian target yang diharapkan dapat tercapai bahkan lebih dari target yakni rencana awal ditargetkan guru dapat menerapkan e learning schoology $75 \%$ ternyata setelah pelaksanaan PKM guru yang dapat menerapkan aplikasi tersebut mencapai $84.90 \%$.
\end{abstract}

KEYWORDS

Workshop , E-Learning, Schoology, Pembelajaran

\section{ARTICLE HISTORY}

Received 02 June 2020

Revised 09 June 2020

Accepted 11 June 2020

\section{CORRESPONDENCE Yeni Asmara @ yeni.stkip@gmail.com}

\section{PENDAHULUAN}

Proses pembelajaran abad ke-21 mengintegrasikan Teknologi dan Komunikasi (TIK) dalam kegiatan pembelajaran. UU Nomor12 Tahun 2012 menjelaskan bahwa Teknologi adalah penerapan dan pemanfaatan berbagai 


\section{JURNAL CEMERLANG: Pengabdian pada Masyarakat \\ P-ISSN 2654-4741 / E-ISSN 2655-7894 \\ Vol. 2, No. 2, Juni 2020, 173 - 183 \\ DOI: https://doi.org/10.31540/jpm.v2i2.920 \\ PENERBIT: LP4MK STKIP PGRI LUBUKLINGGAU}

cabang ilmu pengetahuan yang menghasilkan nilai bagi pemenuhan kebutuhan dan kelangsungan hidup serta peningkatan mutu kehidupan manusia. Proses pembelajaran dengan menggunakan TIK dapat dilakukan baik sebagai sarana penunjang pembelajaran maupun sebagai akses utama dalam pembelajaran. Dinamika teknologi saat ini mencapai akselerasi yang luar biasa. Teknologi yang dipelajari beberapa tahun yang sudah lalu mulai tergantikan dengan teknologi yang baru termasuk berbagai cara pembelajaran secara konvensional. Konsep yang kemudian terkenal dengan sebutan e-learning ini membawa pengaruh terjadinya proses perubahan atau transformasi pendidikan dalam bentuk konvensional ke dalam bentuk digital, baik secara isi dan sistemnya (Agustina, 2013). Pendidikan yang bersifat konvensional yang hanya dibatasi pada pertemuan di sekolah saja tidak dapat memfasilitasi siswa secara kompleks. Dikarenakan kebutuhan belajar siswa yang berbeda-beda dan waktu yang tersedia bagi guru dan siswa dalam pelaksanaan pembelajaran dikelas sangat terbatas.

Bentuk perkembangan teknologi informasi yang dapat dimanfaatkan sebagai media pembelajaran adalah menggunakan e-learning. E-learning merupakan inovasi yang dapat dimanfaatkan dalam proses pembelajaran, tidakhanya dalam penyampaian materi pembelajaran tetapi juga perubahan dalam kemampuan berbagai kompetensi peserta didik. Melalui e-learning, peserta didik tidak hanya mendengarkan uraian materi dari pendidik saja tetapi juga aktif mengamati, melakukan, mendemonstrasikan, dan sebagainya. Materi bahan ajar dapat divirtualisasikan dalam berbagai format sehingga lebih menarik dan lebih dinamis sehingga mampu memotivasi peserta didik untuk lebih jauh dalam proses pembelajaran.

Berdasarkan hasil wawancara dengan kepala SMP Bakti Ibu 11 Lubuklinggau diperoleh informasi bahwa guru-guru di sekolah tersebut belum pernah mendapatkan pelatihan tentang pembelajaran e-learning; menggunakan LMS Schology. Disamping itu permasalahan yang dihadapi mitra adalah guruguru pada umumnya melaksanakan proses pembelajaran dengan menggunakan 


\section{JURNAL CEMERLANG: Pengabdian pada Masyarakat \\ P-ISSN 2654-4741 / E-ISSN 2655-7894 \\ Vol. 2, No. 2, Juni 2020, 173 - 183 \\ DOI: https://doi.org/10.31540/jpm.v2i2.920 \\ PENERBIT: LP4MK STKIP PGRI LUBUKLINGGAU}

metode yang biasa digunakan pada pembelajaran konvensional antara lain metode ceramah, metode tanya jawab, metode diskusi, dan metode penugasan. Menurut Sinarno Surakhmad dalam Suryobroto (2009) yang dimaksud dengan ceramah sebagai metode mengajar yaitu penerangan dan penuturan secara lisan oleh guru untuk peningkatan kelasnya. Selama ceramah berlangsung, guru dapat menggunakan alat-alat bantu seperti gambar, slide powerpoint agar uraiannya menjadi lebih jelas.

Sumber belajar yang digunakan saat proses pembelajaran berlangsung mengacu pada modul yang dimiliki oleh guru, sehingga proses pembelajaran menjadi membosankan. Jumlah peserta didik yang relatif banyak berpotensi mengurangi kualitas interaksi antara guru dan pesertadidik, sehingga hasil yang dicapai kurang maksimal. Dalam pembelajaran konvensional, penyampaian materi sepenuhnya dilakukan di dalam kelas, kegiatan seperti ini yang menyebabkan materi pembelajaran tidak dapat tersampaikan seluruhnya. Dalam proses pembelajaran guru dituntut memilih metode pembelajaran yang dapat meningkatkan hasil belajar siswa. Permasalahan tersebut dapat di pecahkan melalui e-learning (Sukamto, 2012).

Seperti yang telah dijelaskan sebelumnya bahwa pengadian ini didasarkan pada permasalahan bahwa saat ini pendidikan dihadapkan dengan berbagai macam kemajuan IPTEK yang mempengaruhi perkembangan strategi pengajaran dan pembelajaran. Pesatnya perkembangan IPTEK tersebut belum mampu dioptimalisasikan oleh tenaga pendidik untuk mentransformasi kebudayaan, pengetahuan dan keterampilan pada peserta didik guna mencapai tujuan pendidikan yang telah ditetapkan.Sebagai contoh pada umumnya guru belum mampu mengembangkan kompetensi pedagogiknya dalam hal pemanfaatan teknologi sebagai media pendukung dalam proses pembelajaran sehingga dapat menimbulkan minat dan motivasi belajar bagi peserta didik yang sesuai dengan kebutuhan saat ini yakni dengan menggunakan pendekatan berbasis IT seperti menggunakan e-learning. 


\section{JURNAL CEMERLANG: Pengabdian pada Masyarakat \\ P-ISSN 2654-4741 / E-ISSN 2655-7894 \\ Vol. 2, No. 2, Juni 2020, 173 - 183 \\ DOI: https://doi.org/10.31540/jpm.v2i2.920 \\ PENERBIT: LP4MK STKIP PGRI LUBUKLINGGAU}

E-learning merupakan inovasi yang dapat dimanfaatkan dalam proses pembelajaran, tidakhanya dalam penyampaian materi pembelajaran tetapi juga perubahan dalam kemampuan berbagai kompetensi peserta didik. E-learning adalah teknologi informasi dan komunikasi untuk mengaktifkan siswa untuk belajar kapanpun dan dimanapun (Dahiya, 2012). Para pengajar dapat menyediakan bahan-bahan pelajaran untuk peserta didik (siswa), mengontrol materi yangdiajarkan, mengeksplorasi kegiatan masing-masing peserta seperti kita absensi online, pengumpulan tugas, dan lain-lain. Kadang-kadang, pengajar jugadapat mengatur chat online dengan peserta, mengumumkan beberapa informasi, dan memberikan masukan berharga bagi siswanya (Abdillah, 2013).

Bentuk perkembangan teknologi informasi yang dapat dimanfaatkan sebagai media pembelajaran adalah menggunakan e-learning. Melalui e-learning, peserta didik tidak hanya mendengarkan uraian materi dari pendidik saja tetapi juga aktif mengamati, melakukan, mendemonstrasikan, dan sebagainya. Materi bahan ajar dapat divirtualisasikan dalam berbagai format sehingga lebih menarik dan lebih dinamis sehingga mampu memotivasi peserta didik untuk lebih jauh dalamproses pembelajaran. E-learning merupakanproses belajar secara efektif yang dihasilkan dengancara menggabungkan penyampaian materi secaradigital yang terdiri dari dukungan dan layanan dalambelajar (Karwati, 201 4). Menurut Karwati (201 4), secara lebih rinci ,manfaat e-learning dapat dilihat dari 2 sudut, yaitu: (1) Dari Sudut Mahasiswa: e-learning memungkinkan berkembangnya fleksibilitas belajar yang tinggi.

Pentingnya workshop pemanfaatan e-learning : schoology dalam pembelajaran pada guru sekolah menengah diharapkan dapat memberikan suasana dan strategi akademik baru dan berbeda baik bagi guru maupun siswa sehingga dapat meningkatkan minat dan motivasi belajar siswa yang kemudian akan memberikan dampak akan tercapainya tujuan pembelajaran. Dengan pemanfaatan e-learning diharapkan mampu meningkatkan hasil belajar siswa baik berfungsi sebagai suplemen (tambahan), komplemen (pelengkap), maupun substitusi setiap 


\section{JURNAL CEMERLANG: Pengabdian pada Masyarakat \\ P-ISSN 2654-4741 / E-ISSN 2655-7894 \\ Vol. 2, No. 2, Juni 2020, 173 - 183 \\ DOI: https://doi.org/10.31540/jpm.v2i2.920 \\ PENERBIT: LP4MK STKIP PGRI LUBUKLINGGAU}

akhir pembelajaran. Penggunaan media pembelajaran online sebagai sistem (pengganti) pembelajaran konvensional sesuai dengan pernyataan Siahaan (Darmawan, 2014).

\section{MASALAH}

Pada saat ini pendidikan dihadapkan dengan berbagai macam kemajuan IPTEK yang mempengaruhi perkembangan strategi pengajaran dan pembelajaran. Pesatnya perkembangan IPTEK tersebut belum mampu dioptimalisasikan oleh tenaga pendidik untuk mentransformasi kebudayaan, pengetahuan dan keterampilan pada peserta didik guna mencapai tujuan pendidikan yang telah ditetapkan. Sebagai contoh pada umumnya guru belum mampu mengembangkan kompetensi pedagogiknya dalam hal pemanfaatan teknologi sebagai media pendukung dalam proses pembelajaran sehingga dapat menimbulkan minat dan motivasi belajar bagi peserta didik yang sesuai dengan kebutuhan saat ini yakni dengan menggunakan pendekatan berbasis IT seperti menggunakan e-learning schoology. Kondisi ini dialami oleh guru-guru yang mengajar di SMP Bakti Ibu 11 Lubuklinggau, yang belum memahami tentang pembelajaran e-learning, yang rata-rata hanya menerapkan metode pembelajaran konvensional, serta belum memanfaatkan teknologi yang dimiliki sebagai upaya meningkatkan kualitas pembelajaran.

\section{METODE}

Pengabdian pada Masyarakat dengan judul "Workshop Pemanfaatan $e$ learning: Schoology dalam pembelajaran" diselenggarakan dengan menggunakan tahap-tahap pelaksanaan seperti mengadakan kontrak kerjasama dengan kepala sekolah sebagai mitra, selanjutnya jika usulan pengabdian ini diterima maka tahap berikutnya akan dilakukan penyebaran undangan kepada guru-guru yang mengajar di sekolah terkait dengan pelaksanaan kegiatan tersebut. Kemudian akan diadakan kegiatan workshop. Adapun sistem penyampaian materi dalam kegiatan workshop 


\footnotetext{
JURNAL CEMERLANG: Pengabdian pada Masyarakat

P-ISSN 2654-4741 / E-ISSN 2655-7894

Vol. 2, No. 2, Juni 2020, 173 - 183

DOI: https://doi.org/10.31540/jpm.v2i2.920

PENERBIT: LP4MK STKIP PGRI LUBUKLINGGAU
}

ini adalah dengan menggunakan metode ceramah yang dikombinasikan dengan metode demosntrasi dan latihan. Selanjutnya di akhir kegiatan akan diberikan evaluasi kepada guru yang mengikuti kegiatan tersebut dengan indicator keberhasilan kemampuan guru dalam menggunakan e-learning.

Penggunaan metode ceramah yang dikombinasikan dengan metode demonstrasi dan latihan pada kegiatan workshop sebagai upaya meningkatkan teknik dan strategi pembelajaran dapat berjalan dengan efektif dan tercapai apa yang menjadi tujuan dari pengabdian ini. Hal ini sesuaikan dengan hasil penelitian yang dilakukan Ikhwanuddin (2013) bahwa metode tersebut sangat efektif terutama ketika materi yang disampaikan adalah materi yang masih baru atau belum diketahui.

Metode demostrasi dilaksanakan ketika akan menerapkan aksara ulu pada guru-guru dimulai dengan pengenalan huruf dan tanda baca. Selanjutnya metode latihan akan diberikan kepada guru-guru untuk mengetahui sejauhmana kemampuan dalammenerapkan pembelajaran e-learning dengan berbasis internet. Selanjutnya dalam kegiatan workshop ini akan diberikan evaluasi pada bagian akhir berupa penilaian terhadap kemampuan guru dalam mengaplikasikan e learning dalam pembelajaran.

\section{HASIL dan PEMBAHASAN}

Hasil studi pendahuluan pelaksanaan PPM yang telah dilakukan, pada tahap observasi diketahui bahwa dari 53 guru hanya 20 orang guru atau $37.73 \%$ yang dapat mengaplikasikan e-learning schoology sesuai dengan bidang studinya masing-masing. Dan 15 orang guru atau $28.30 \%$ baru berhasil membuat akun aplikasi dari e-learning schoology dikarenakan tidak menggunakan laptop tetapi menggunakan handphone. 18 orang guru atau $33.96 \%$ belum dapat membuat akun dan mengaplikasikan e-learning schoology dikarenakan terkendala tidak membawa laptop dan handphone serta belum memiliki $e$-mail pribadi.

Berdasarkan studi pendahuluan dengan melihat beberapa hasil dari 


\section{JURNAL CEMERLANG: Pengabdian pada Masyarakat \\ P-ISSN 2654-4741 / E-ISSN 2655-7894 \\ Vol. 2, No. 2, Juni 2020, 173 - 183 \\ DOI: https://doi.org/10.31540/jpm.v2i2.920 \\ PENERBIT: LP4MK STKIP PGRI LUBUKLINGGAU}

penelitian yang relevan yaitu hasil penelitian yang dilakukan oleh Edy (2011 ) mengenai pemanfaatan website elearning diperoleh hasil berikut : (1) Tingkat pemanfaatan e-learning berpengaruh positif dan siginifikan terhadap motivasi belajar; (2) Tingkat pemanfaatan e-learning berpengaruh positif dan siginifikan terhadap kinerja individu; (3) Motivasi berpengaruh positif dan signifikan terhadap hasil belajar; (4) Kinerja individu berpengaruh positif dan signifikan terhadap hasil belajar; (5) Tingkat pemanfaatan e-learning berpengaruh negatif dan tidak siginifikan terhadap hasil belajar. Selanjutnya hasil penelitian yang dilakukan Agustina (2013) pada pemanfaatan e-learning didapakan hasil sebagai berikut: Pemanfaatan e-learning sebagai media pembelajaran berada pada kondisi cukup baik, dibuktikan dengan hasil pengolahan terhadap data yang diperoleh langsung dari para responden dengan persentase sebesar 28.5\%, kondisi baik 21 $.6 \%$ dan $10.1 \%$ sangat baik. Berdasarkan beberapa hasil penelitian yang terdahulu dapat disimpulkan penggunaan e-learning berdampak positif untuk pembelajaran.

Sedangkan pelaku utama yang ada dalam pelaksanakan e-learning dapat dimaksudkan sama dengan proses belajar mengajar konvensional, yaitu perlu adanya pengajar (dosen) yang membimbing siswa (peserta didik) yang menerima bahan ajar dan administrator yang mengelola administrasi dan proses belajar mengajar. E-learning dapat membawa suasana baru dalam ragam pengembangan pembelajaran. Pemanfaatan e-learning dengan baik dapat meningkatkan hasil pembelajaran dengan maksimal. Beberapa manfaat dari e-learning diantaranya menurut Rohmah (2016) (1) dengan adanya e-learningmaka dapat mempersingkat waktu pembelajaran dan membuat biaya studi lebih ekonomis (2) E-learning mempermudah interaksi antara peserta didik dengan bahan materi, (3) Peserta didik dapat saling berbagi informasi dan dapat mengakses bahan-bahan belajar setiap saat dan berulang-ulang, dengan kondisi yang demikian itu peserta didikdapat lebih memantapkan penguasaannya terhadap materi pembelajaran (4) Dengan e-learning proses pengembangan pengetahuan tidak hanya terjadidi dalam 


\section{JURNAL CEMERLANG: Pengabdian pada Masyarakat \\ P-ISSN 2654-4741 / E-ISSN 2655-7894 \\ Vol. 2, No. 2, Juni 2020, 173 - 183 \\ DOI: https://doi.org/10.31540/jpm.v2i2.920 \\ PENERBIT: LP4MK STKIP PGRI LUBUKLINGGAU}

ruangan kelas saja, tetapi dengan bantuan peralatan komputer dan jaringan, para siswa dapat secara aktif dilibatkan dalam proses belajar-mengajar.

Pertemuan kedua ada 45 orang guru atau $84.90 \%$ guru yang telah memiliki akun dan membuat aplikasi e-learning schoology sesuai dengan bidang studinya masing-masing. Dan 8 orang atau $15.09 \%$ guru sampai pada tahap pembuatan akun. Dengan demikian target yang diharapkan dapat tercapai bahkan lebih dari target yakni rencana awal ditargetkan guru dapat menerapkan e learning schoology $75 \%$ ternyata setelah pelaksanaan PKM guru yang dapat menerapkan aplikasi tersebut mencapai $84.90 \%$.

Salah satu e-learning berbasis Learning Management System (LMS) yang berfungsi sebagai platform pelajaran-pelajaran e-learning. yang sesuai untuk digunakan adalah Schoology, schoology disajikan dalam bentuk pembelajaran berbasis internet atau yang seirng disebut dengan e-learning. Aminoto dan Pathoni (2014) menyatakan bahwa Schoology merupakan salah satu laman web yang berbentuk web sosial yang menawarkan pembelajaran sama seperti di dalam kelas secara gratis dan mudah digunakan seperti facebook. Media Schoology memungkinkan guru untuk melakukan kegiatan belajar mengajar dengan siswa di luar kelas seperti mengadakan dan memantau jalannya diskusi melalui media Schoology dan siswa dapat berperan secara langsung didalamnya. Kelebihan media Schoology adalah didukung oleh berbagai bentuk media seperti video, audio, dan gambar yang dapat menarik perhatian siswa terhadap kegiatan pembelajaran. Schoology juga memiliki fitur yang sangat lengkap dengan berbagai alat pembelajaran sama seperti dikelas seperti absensi, tes dan kuis, dan kotak untuk mengumpulkan tugas atau pekerjaan rumah. Schoology mengarahkan siswa mengaplikasikan penggunaan teknologi dalam pembelajaran.

Menurut (Amiroh, 2013) menyebutkan beberapa kelebihan dari schoology, antara lain: (a) Schoology menyediakan lebih banyak pilihan resources daripada yang disediakan oleh Edmodo; (b) Schoology dapat menampung jenis soal (question bank) yang akan digunakan saat kuis; (c) Schoology menyediakan 
JURNAL CEMERLANG: Pengabdian pada Masyarakat

P-ISSN 2654-4741 / E-ISSN 2655-7894

Vol. 2, No. 2, Juni 2020, 173 - 183

DOI: https://doi.org/10.31540/jpm.v2i2.920

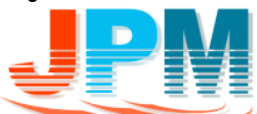

PENERBIT: LP4MK STKIP PGRI LUBUKLINGGAU

fasilitas attandance absensi yang digunakan untuk mengecek kehadiran siswa; (d) Schoology juga menyediakan fasilitas analityc untuk melihat semua aktivitas siswa pada setiap course, assignment, discussion dan aktivitas lain yang disiapkan untuk siswa. Berikut dokumentasi kegiatan PKM Workshop Pemanfaatan ELearning : Schoology dalam Pembelajaran Pada Guru Sekolah Menengah Di SMP BI (Bakti Ibu) 11 Lubuklinggau:

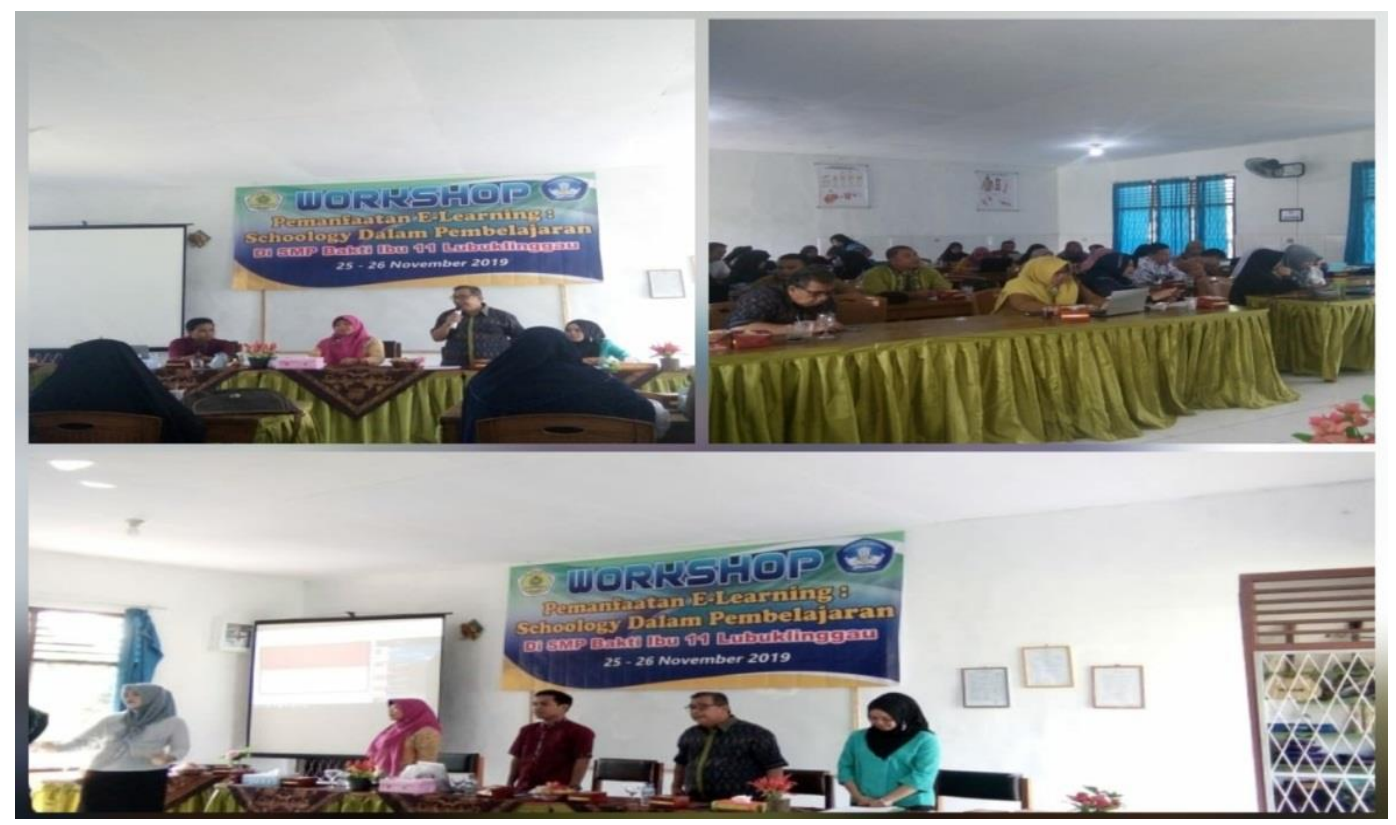

Gambar 1 (Suasana Pembukaan Kegiatan PKM)

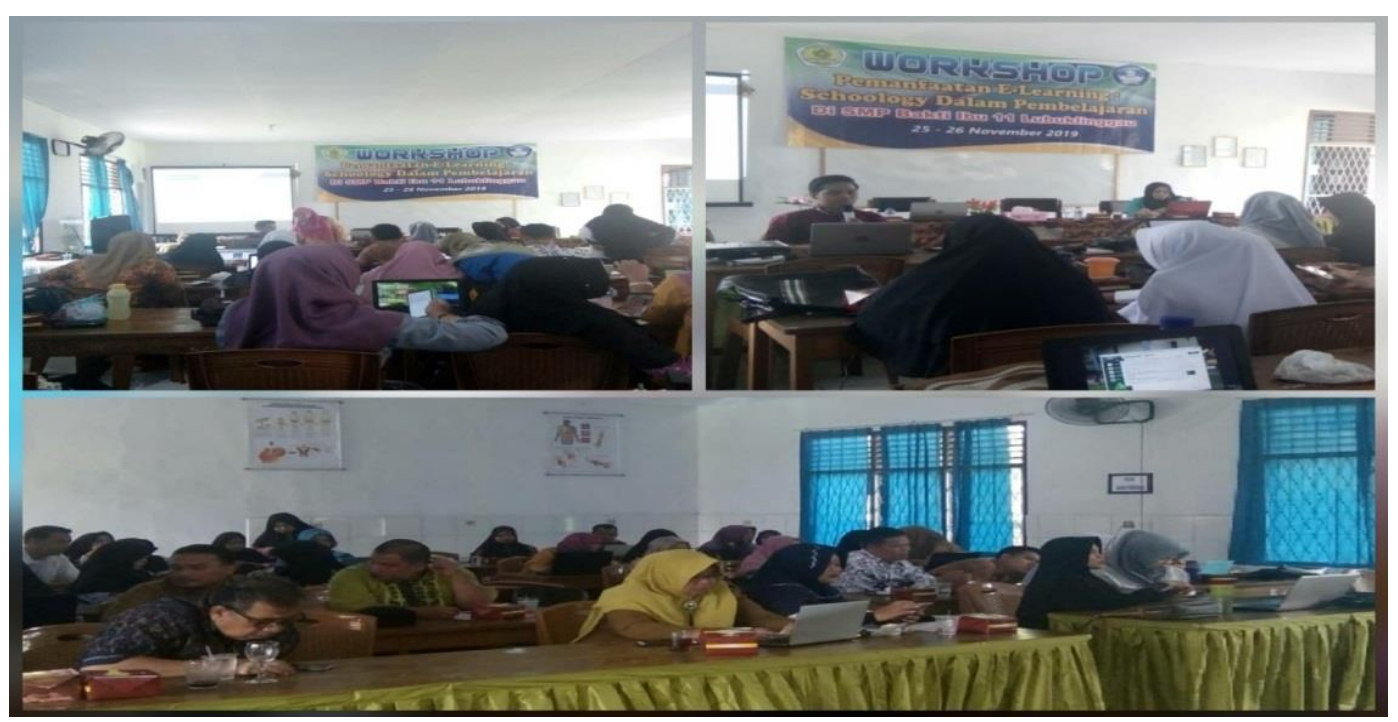

Gambar 2 (Suasana Workshop E-Learning;Schoology)

https://ojs.stkippgri-lubuklinggau.ac.id/index.php/JPM 


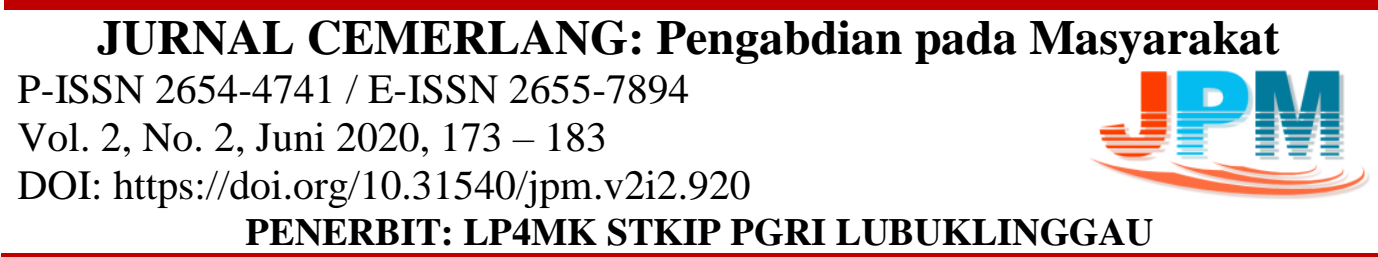

Pelaksanaan kegiatan ini mendapat apresiasi positif dan dukungan baik dari sekolah maupun peserta, mereka mengharapkan agar kegiatan pelatihan ini dapat terus dilakukan karena sangat membantu sekali dalam memberikan pemahaman dan keterampilan bagi guru terutama pemanfaatan Teknologi Informasi dan Komunikasi yang dapat diintegrasikan dalam proses pembelajaran sehingga memberikan kemudahan baik dari segi guru maupun siswa untuk melaksankan proses pembelajaran dan mencapai tujuan pembelajaran yang hendak dicapai.

\section{SIMPULAN}

Dari hasil kegiatan PPM ini dapat disimpulkan bahwa kegiatan tersebut sangat mendapat dukungan dan apresiasi positif yang tinggi dari dari pihak sekolah baik Kepala Sekolah maupun para guru karena kegiatan tersebut sebelumnya belum pernah dilaksanakan di sekolah. Berdasarkan hasil evaluasi dari dua kali pertemuan yang dilaksanakan dapat diketahui bahwa pada pertemuan pertama hanya 20 orang guru yang dapat mengaplikasikan e-learning: schoology dari 53 peserta atau sekitar $37.73 \%$, hal ini disebabkan pada pertemuan pertama guru pada ummnya hanya menggunakan handphone dan ada yang tidak membawa laptop sehingga mengalami kesulitan untuk mengaplikasikan e-learning tersebut. Pada pertemuan kedua sebanyak 46 orang guru atau sekitar $86.79 \%$ yang telah mampu mengoperasikan e-learning dalam bentuk schoology dengan benar.

\section{DAFTAR PUSTAKA}

Abdillah, Leon Andretti. Students Learning Centre Strategy Based on E-Learning and Blogs. Providing SNST ke-4 Tahun 201 3, Fakultas Teknik Universitas Wahid Hasyim Semarang. 2013.

Agustina, Merry. Pemanfaatan E-Learning sebagai Media Pembelajaran. Seminar Nasional Aplikasi Teknologi Informasi, Yogyakarta, 15 Juni 2013.

Amiroh. 2012. Under E-Learning, Edmodo, Moodle and Schoology. Online (http://amiroh.web.id). Diakses pada tanggal 28 Oktober 2019.

AminotodanPathoni, 2014. Penerapan Media E-Learning Berbasis Schoology 


\footnotetext{
JURNAL CEMERLANG: Pengabdian pada Masyarakat

P-ISSN 2654-4741 / E-ISSN 2655-7894

Vol. 2, No. 2, Juni 2020, 173 - 183

DOI: https://doi.org/10.31540/jpm.v2i2.920

PENERBIT: LP4MK STKIP PGRI LUBUKLINGGAU
}

untuk Meningkatkan Aktivitas dan Hasil Belajar Materi Usaha danEnergi di Kelas XI SMAN 10 Kota Jambi. Jurnal Sainmatika. Vol. 8 No. 1. 2014.

Dahiya, S., Jaggi, S., Chaturvedi, K.K., Bhardwaj, A., Goyal, R.C. and Varghese, C., 2016.An eLearning System for Agricultural Education.Indian Research Journal of Extension Education, 12(3), 2012.

Ikhsanudin, Arief, 2015. Historia Masa Lampau selalu Actual. Diakses 3 Desember 2018 http://historia.id.budaya.articles.

Karwati, Euis. Pengaruh Pembelajaran Elektronik (E-Learning) Terhadap Mutu Belajar Mahasiswa. Jurnal Penelitian Komunikasi Vol. 17 No.1 , 2014.

Munir. Pembelajaran jarak jauh berbasis teknologi informasi dan komunikasi. Bandung: Alfabeta. 2009.

OECD (2015). Programme for International Student Assessment (PISA). Diakses dari http://www.oecd.org/pisa/PISA-2015-Indonesia.pdf padatanggal 28 Oktober 2019.

Rohmah, 2016. Konsep E-Learning Dan Aplikasinya Pada Lembaga Pendidikan Islam. JurnalAn-Nur, 3(2). 2016.

Siahaan, E-learning sebagai Salah satu alternatif kegiatan pemebelajaran," Jurnal Pendidikan dan Kebudayaan, Vol 3 No.1. 2003.

Sukamto, Binar Cipta Anggara. E-learning Jaringan Komputer Berbasis Web dan Aplikasi Mobile. Journal Teknik Elektro, Vol.1 No. 2. 2012. 